Corrigendum

\title{
Corrigendum to "Heat Shock Protein 70 and 90 Genes in the Harmful Dinoflagellate Cochlodinium polykrikoides: Genomic Structures and Transcriptional Responses to Environmental Stresses"
}

\author{
Ruoyu Guo, ${ }^{1}$ Seok Hyun Youn, ${ }^{2}$ and Jang-Seu Ki ${ }^{1}$ \\ ${ }^{1}$ Department of Life Science, Sangmyung University, Seoul 110-743, Republic of Korea \\ ${ }^{2}$ Fishery and Ocean Information Division, National Fisheries Research \& Development Institute, Busan 619-705, Republic of Korea \\ Correspondence should be addressed to Jang-Seu Ki; kijs@smu.ac.kr \\ Received 7 September 2015; Accepted 9 September 2015 \\ Copyright (C) 2015 Ruoyu Guo et al. This is an open access article distributed under the Creative Commons Attribution License, \\ which permits unrestricted use, distribution, and reproduction in any medium, provided the original work is properly cited.
}

In Materials and Methods (2.3. Gene Sequences Determination), in the paper titled "Heat Shock Protein 70 and 90 Genes in the Harmful Dinoflagellate Cochlodinium polykrikoides: Genomic Structures and Transcriptional Responses to Environmental Stresses" [1], we have cited wrong GenBank accession number SRR1917383; the correct GenBank accession number is SRR1548539.

\section{References}

[1] R. Guo, S. H. Youn, and J.-S. Ki, "Heat shock protein 70 and 90 genes in the harmful dinoflagellate Cochlodinium polykrikoides: genomic structures and transcriptional responses to environmental stresses," International Journal of Genomics, vol. 2015, Article ID 484626, 12 pages, 2015. 

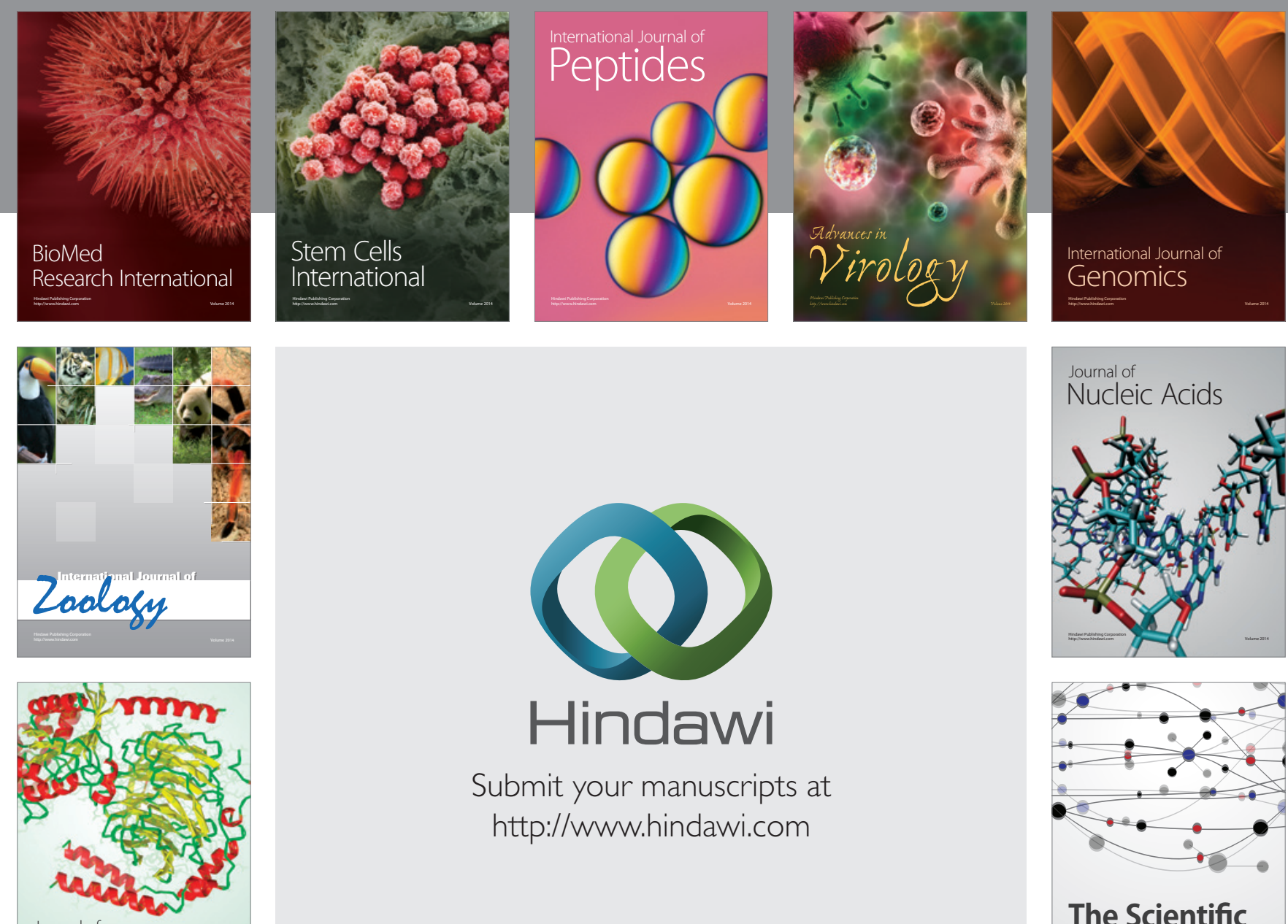

Submit your manuscripts at

http://www.hindawi.com

Journal of
Signal Transduction
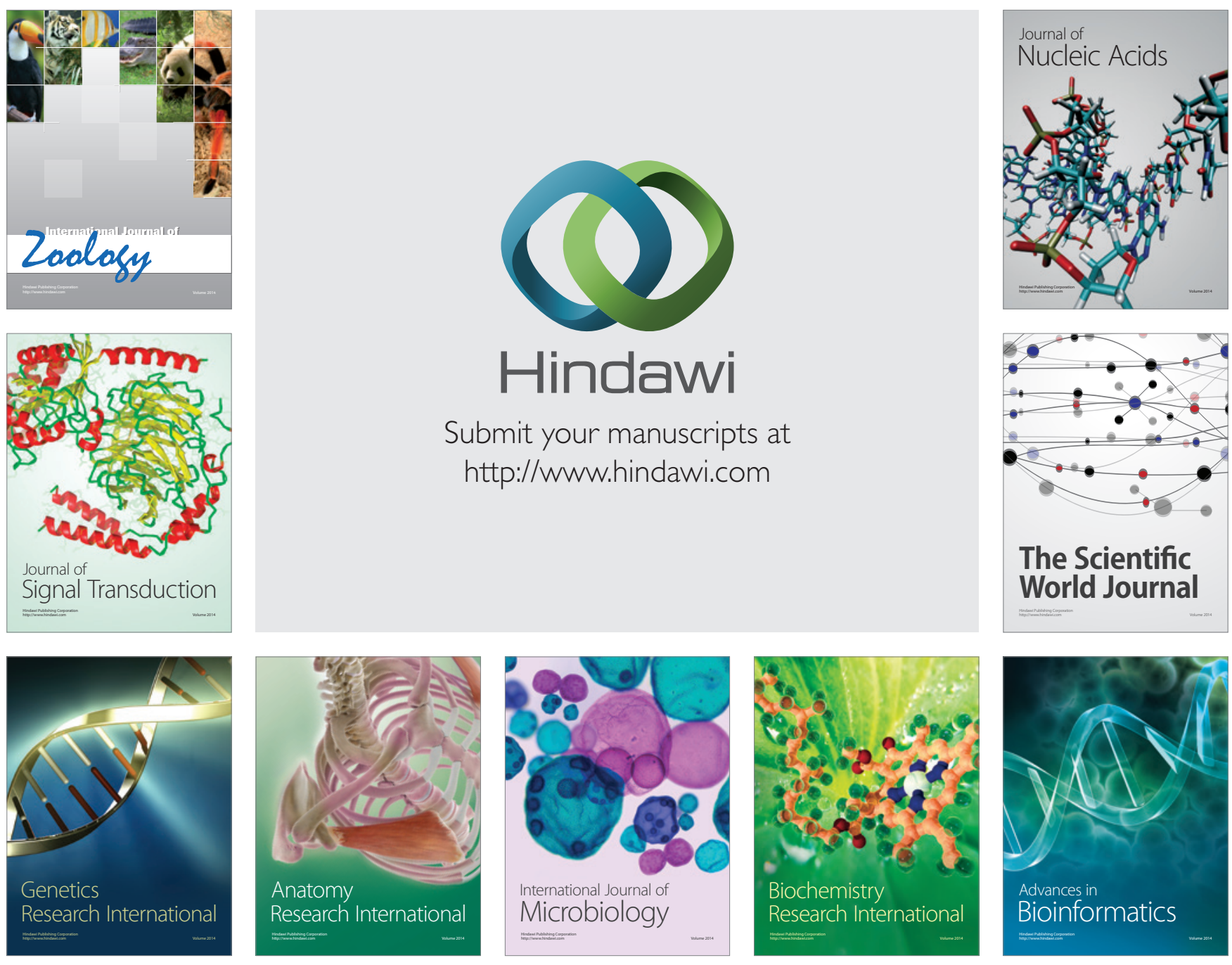

The Scientific World Journal
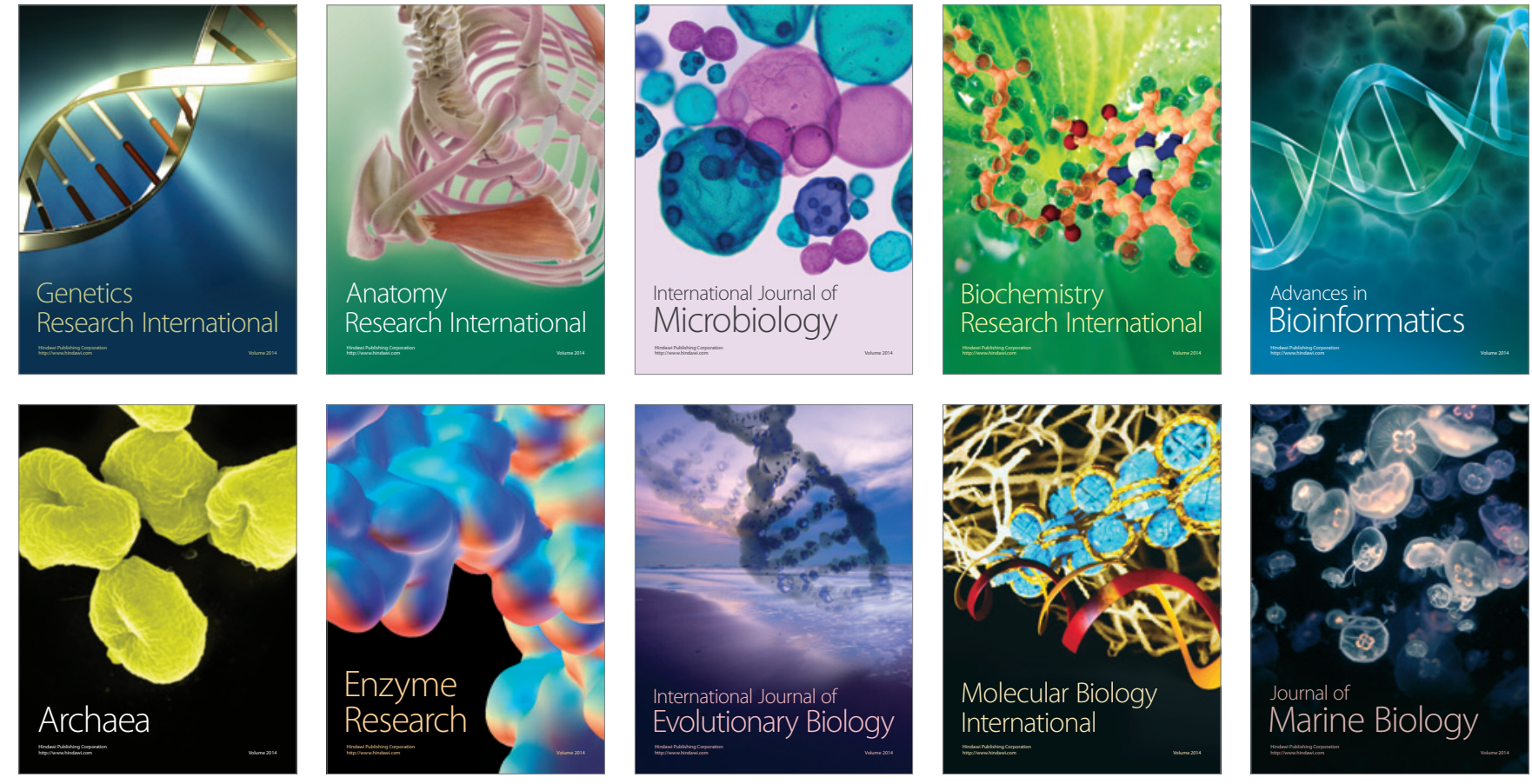